\title{
Isolation and Restriction Analysis of DNA from Heterocysts and Vegetative Cells of Cyanobacteria
}

\author{
By DAVID G. ADAMS \\ Department of Microbiology, University of Leeds, Leeds LS2 9JT, UK
}

(Received 11 February 1988; revised 31 May 1988)

\begin{abstract}
A procedure was developed for the isolation of heterocysts from cyanobacterial filaments without recourse to mechanical disruption of the vegetative cells. DNA was then extracted from purified heterocysts by heating with $2 \%(\mathrm{w} / \mathrm{v}) \mathrm{SDS}$ at $70^{\circ} \mathrm{C}$ for $10 \mathrm{~min}$. Following purification, this DNA was used for treatment with a range of restriction endonucleases and the results compared with DNA isolated from vegetative cells. Both heterocyst and vegetative DNAs from Anabaena PCC 7120 and Anabaena CA (ATCC 33047) were cut by XbaI, HindIII, EcoRI, ClaI, $H p a I I$ and $M s p I$. However, none of the DNAs were cut by XhoI, SalI or MboI, indicating that the DNA from both organisms is methylated, but that no gross changes in methylation occur during heterocyst formation. Treatment of the DNAs with the former enzymes, followed by separation of the fragments by agarose gel electrophoresis, resulted in most cases in patterns of bands, which allowed a limited comparison of heterocyst and vegetative DNAs. No major differences were seen between the heterocyst and vegetative DNAs of either organism, implying that there are unlikely to be extensive rearrangements or major loss of DNA during heterocyst differentiation.
\end{abstract}

\section{INTRODUCTION}

Cyanobacteria are photosynthetic prokaryotes which show a remarkable degree of morphological and developmental diversity (see Adams \& Carr, 1981). When grown in the presence of a source of fixed nitrogen such as ammonium chloride, many species exist as long, undifferentiated filaments of vegetative cells. Removal of the nitrogen source elicits the development of highly specialized cells known as heterocysts which provide the sites for nitrogen fixation (see Wolk, 1982). Very little is known about the control of gene expression during this process, although a complex and ordered sequence of events occurs during the transformation of a vegetative cell into a proheterocyst (an intermediate stage) and then into a mature heterocyst (see Adams \& Carr, 1981). Proheterocysts can dedifferentiate under the appropriate conditions, but the mature heterocyst cannot (see Adams \& Carr, 1981). This has led to much speculation about the DNA content of heterocysts and indeed the mature cells do not show the fibrous DNA-containing material normally present in vegetative cells (Lang \& Fay, 1971) and have reduced ultraviolet absorption (Fogg, 1951). Fluorescent methods have shown the presence of DNA in heterocysts (Ueda, 1971; Ueda \& Sawada, 1972) but it is only relatively recently that a measurement of the DNA content has been reported (Simon, 1980). This indicated that heterocysts contained about the same amount of DNA as vegetative cells, but shed no light on the possibility of modification of the DNA in heterocysts. It is known that DNA from various cyanobacteria is methylated, rendering it refractory to a number of restriction endonucleases (Van den Hondel et al., 1983; Lambert \& Carr, 1984). Much of this modification cannot be explained in terms of protecting the organism's DNA from its own type II restriction endonucleases (Lambert \& Carr, 1984). Indeed, methylation has been detected in a strain which lacks detectable sequence-specific endonucleases (Lambert \& Carr, 1984). DNA methylation is 
well documented in prokaryotes and has been implicated in the regulation of gene expression during differentiation in eukaryotes (see Doerfler, 1983).

The work described here set out to isolate, from heterocysts, DNA of sufficiently high purity and physical integrity to permit analysis with restriction endonucleases and provide a comparison with vegetative DNA.

\section{METHODS}

Organisms and growth. Anabaena 7120 (Pasteur Culture Collection) was grown at $34^{\circ} \mathrm{C}$ in the medium of Allen \& Arnon (1955) $\left(\mathrm{A}_{2}\right)$ supplemented with $4 \mathrm{mM}-\mathrm{NH}_{4} \mathrm{Cl}\left(\mathrm{A}_{2} \mathrm{~N}_{4}\right)$. Anabaena $\mathrm{CA}$ (American Type Culture Collection no. 33047) was grown at $39^{\circ} \mathrm{C}$ in BG-11 medium (Stanier \& Cohen-Bazire, 1977), modified by the addition of $4.39 \mathrm{~g} \mathrm{NaCl} \mathrm{l}^{-1}$ and increasing $\mathrm{MgSO}_{4} .7 \mathrm{H}_{2} \mathrm{O}$ to $5.00 \mathrm{~g} \mathrm{t}^{-1}$ and $\mathrm{CaCl}_{2} \cdot 2 \mathrm{H}_{2} \mathrm{O}$ to $0.521 \mathrm{~g} \mathrm{t}^{-1}$. The medium was buffered with HEPES $\left(0.5 \mathrm{~g} \mathrm{t}^{-1}\right)$ and adjusted to $\mathrm{pH} 8$ with $\mathrm{NaOH}$ prior to autoclaving. For vegetative cells the cultures were grown in 1 litre glass reaction vessels and filaments maintained in suspension by magnetic stirring. Light was provided by $20 \mathrm{~W}$ warm white fluorescent strip lamps, two for Anabaena 7120 and four for Anabaena $\mathrm{CA}$, placed $15 \mathrm{~cm}$ from the centre of the growth vessel. For the large quantities of cells required for heterocyst isolation, cultures were grown semi-continuously in a 121 fermenter (New Brunswick Scientific $\mathrm{Co}$.) in $\mathrm{A}_{2}$ medium for Anabaena 7120 or modified BG-11 lacking $\mathrm{NaNO}_{3}$ for Anabaena CA. During exponential growth 8-101 of culture were harvested in a continuous flow centrifuge, the cells washed once in TEM buffer ( $50 \mathrm{mM}-\mathrm{Tris} / \mathrm{HCl} \mathrm{pH}$ $8.5,25 \mathrm{~mm}$-EDTA, $25 \mathrm{~mm}$-mannitol) and the pellet stored at $-20^{\circ} \mathrm{C}$. The fermenter was refilled with sterile medium, the 2-4 1 remaining from the previous culture serving as an inoculum. The culture was grown once more and harvested as before. This process was repeated until sufficient cells were obtained. All cultures were gassed with sterile $5 \% \mathrm{CO}_{2}$ in air.

Heterocyst isolation. The pellet from 201 of culture was allowed to thaw, resuspended to $100-200 \mathrm{ml}$ in TEM and gently homogenized in a Potter homogenizer. The cell suspension was incubated with lysozyme $\left(1 \mathrm{mg} \mathrm{ml}^{-1}\right)$ at $37^{\circ} \mathrm{C}$ for $2 \mathrm{~h}$ and gently homogenized once more. Unless otherwise indicated, the remainder of the procedure was done at $2-4{ }^{\circ} \mathrm{C}$. The volume was made up to $500 \mathrm{ml}$ with TEM and the suspension centrifuged at $280 \mathrm{~g}$ for $30 \mathrm{~min}$. This resulted in a hard, yellowish pellet consisting mostly of heterocysts, covered by a loose jelly-like pellet of heterocysts, vegetative cell debris and polysaccharide, and a clear green supernatant. The supernatant was removed and the surface of the pellet washed gently with TEM to remove the loose debris. The pellet was resuspended in TEM, centrifuged at $150 \mathrm{~g}$ for $2.5 \mathrm{~min}$, and the supernatant removed. The washing was repeated if necessary until the heterocyst pellet was free of contaminating vegetative cell debris (see Results).

DNA isolation. Wide-bore pipettes and pipette tips were used throughout the preparation. The heterocyst pellet was resuspended in $10 \mathrm{ml} \mathrm{TE} \mathrm{(10} \mathrm{mM-Tris} / \mathrm{HCl} \mathrm{pH} \mathrm{8.0,1} \mathrm{mM-EDTA)} \mathrm{and} 20 \%$ (w/v) SDS was added to a final concentration of $2 \%$. The mixture was heated at $70{ }^{\circ} \mathrm{C}$ for $10 \mathrm{~min}$ and extracted twice with equal volumes of redistilled phenol (prepared as described in Maniatis et al., 1982) and five times with equal volumes of chloroform/isoamyl alcohol $(24: 1, \mathrm{v} / \mathrm{v})$. The DNA was precipitated by adding $1 / 50 \mathrm{vol} .5 \mathrm{M}-\mathrm{NaCl}$ and 2 vols ethanol which had been pre-cooled at $-20^{\circ} \mathrm{C}$. The solution was centrifuged at $300 \mathrm{~g}$ for $30 \mathrm{~min}$ in a swing-out rotor, the pellet briefly dried under vacuum and resuspended in TE.

For the isolation of vegetative cell DNA, approximately 1 litre of culture grown in the presence of fixed nitrogen was harvested and resuspended in $20 \mathrm{ml}$ TE. The sample was homogenized and incubated with lysozyme $(1 \mathrm{mg}$ $\mathrm{ml}^{-1}$ ) at $37^{\circ} \mathrm{C}$ for $30 \mathrm{~min}$, SDS was added to $2 \%(\mathrm{w} / \mathrm{v})$ final concentration and the mixture heated at $70^{\circ} \mathrm{C}$ for 10 min. The remainder of the preparation was the same as for heterocyst DNA.

DNA purity was checked by scanning a sample between 200 and $300 \mathrm{~nm}$ and calculating the ratios $A_{260}: A_{280}$ and $A_{260}: A_{230}$. The concentration of purified DNA samples was estimated from the $A_{260}$, assuming a value of 1 to be equivalent to $50 \mu \mathrm{g} \mathrm{ml}^{-1}$.

Restriction endonuclease digestion. The enzymes XbaI, HindIII, XhoI, EcoRI, SalI, HpaII and MspI were obtained from Boehringer, Mannheim; ClaI and $\mathrm{MboI}$ from BRL and BstI from Cambridge Biotechnology Laboratories. Incubations were done at $37^{\circ} \mathrm{C}$ for $4 \mathrm{~h}$ and were terminated by the addition of $1 / 15 \mathrm{vol} .0 \cdot 2 \mathrm{M}$-EDTA and $1 / 6$ vol. sample buffer $(0.25 \%$, w/v, bromophenol blue; $0.25 \%$, w/v, xylene cyanol; $40 \%$, w/v, sucrose). Samples not electrophoresed immediately were stored at $2-4{ }^{\circ} \mathrm{C}$. Incubations were done in the appropriate high-, medium- or low-salt buffer (Maniatis et al., 1982). Routinely $10 \mu \mathrm{g}$ chromosomal DNA was incubated with 20 units of restriction enzyme in a final volume of $35 \mu \mathrm{l}$, although the exact volume was determined by the concentration of the enzyme supplied by the manufacturer, since the volume of undiluted enzyme added could not exceed $10 \%$ of the final reaction volume. Approximately $5 \mu \mathrm{g}$ restricted chromosomal DNA was used for each gel slot.

Agarose gel electrophoresis. Samples were electrophoresed at $50 \mathrm{~V}$ for $15 \mathrm{~h}$ in $0.7 \%$ agarose in $40 \mathrm{mM}$-Tris/acetate pH 8.0, 2 mM-EDTA and $0.5 \mathrm{mg}$ ethidium bromide $\mathrm{l}^{-1}$. To reduce background fluorescence, gels were soaked in several changes of distilled water for $3-5 \mathrm{~h}$ prior to photography. $\lambda$ DNA was restricted with HindIII to provide molecular mass standards. 

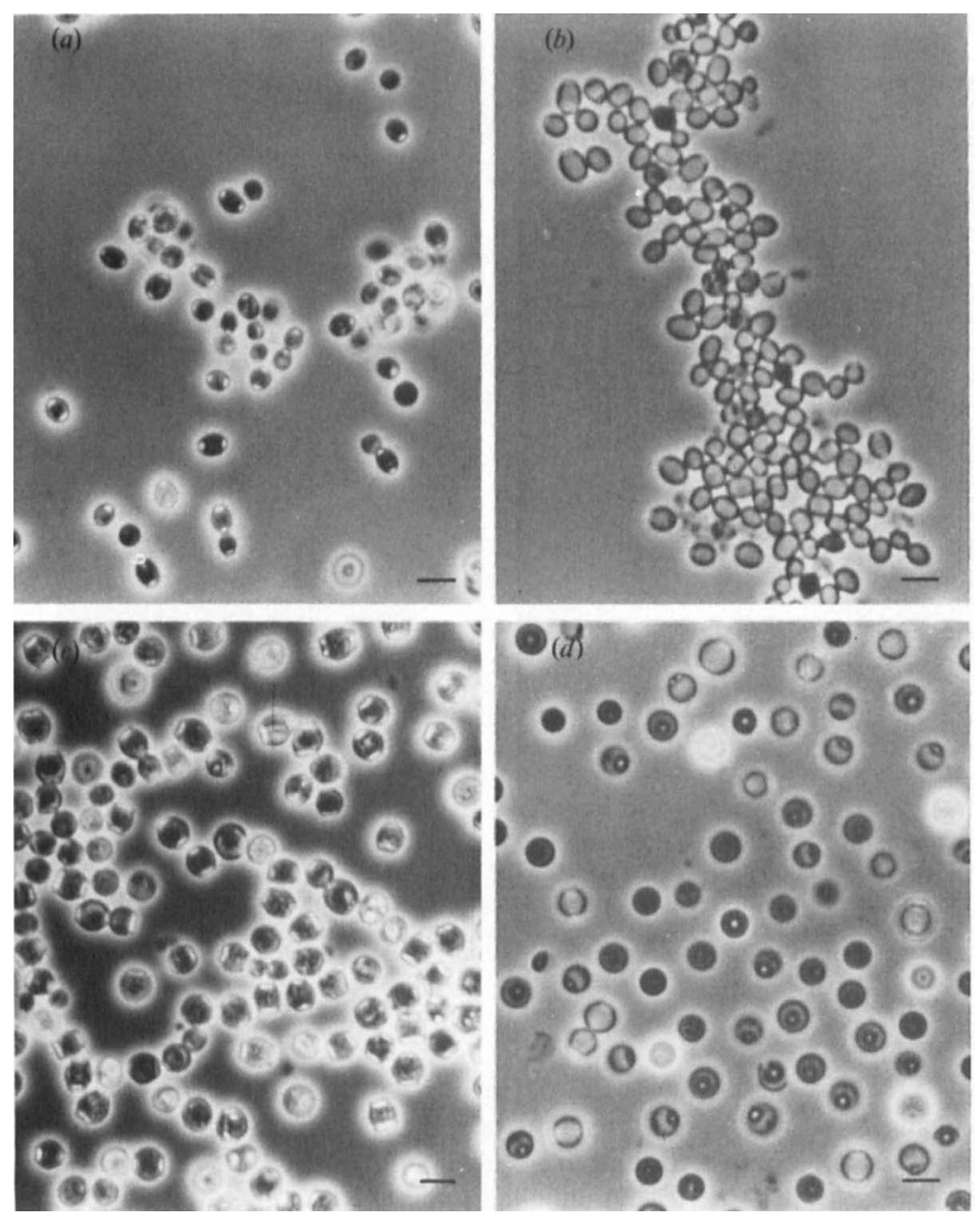

Fig. 1. Phase-contrast photomicrographs of heterocysts isolated from Anabaena $7120(a, b)$ and Anabaena CA $(c, d)$. Heterocysts are shown immediately following their isolation $(a, c)$ and after incubation with $2 \%(\mathrm{w} / \mathrm{v}) \mathrm{SDS}$ at $70^{\circ} \mathrm{C}$ for $10 \mathrm{~min}(b, d)$. Heating with SDS releases the contents of most heterocysts, although a small number may remain intact and phase-bright as in $(d)$. In $(d)$ many heterocysts are being viewed along their longitudinal axis and the point at which they were previously attached to vegetative cells can be seen as a bright spot surrounded by a dark ring. Bars, $10 \mu \mathrm{m}$.

\section{RESULTS}

\section{Heterocyst isolation}

The original method for heterocyst isolation involved treatment of filaments with lysozyme, which weakened vegetative cell walls but had little effect on heterocysts, followed by mechanical disruption of the vegetative cells by sonication or French pressing (Fay \& Walsby, 1966). However, such physical methods of disruption can cause significant damage to the DNA within heterocysts. To avoid this, sonication and French pressing were omitted and the incubation period with lysozyme extended. This, together with freezing of cells at $-20^{\circ} \mathrm{C}$ and gentle but thorough homogenizing before and after lysozyme treatment, was usually sufficient to cause complete lysis of vegetative cells in the two Anabaena species used. Heterocysts could be isolated by careful washing and centrifugation. The purity of preparations was checked by microscopic examination using phase-contrast optics and washing was continued until no vegetative cell debris was visible (see Fig. 1). It was clearly important to ensure that no significant amount of 
(a)

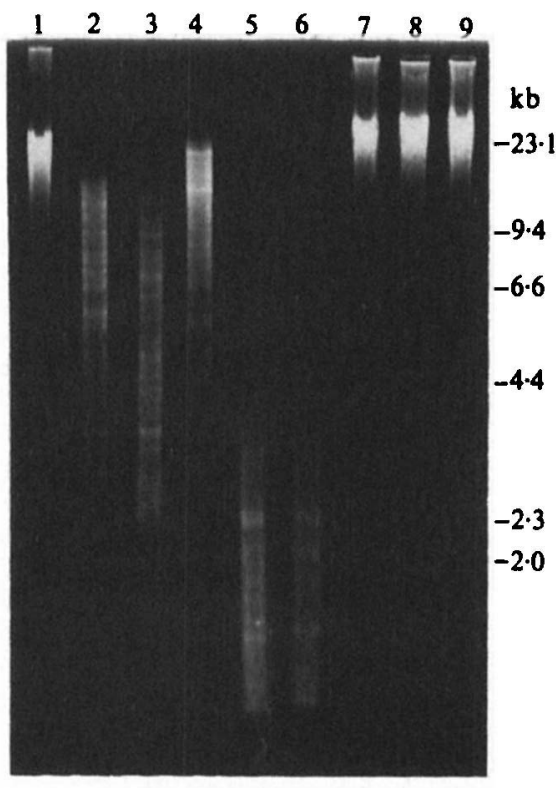

(b)

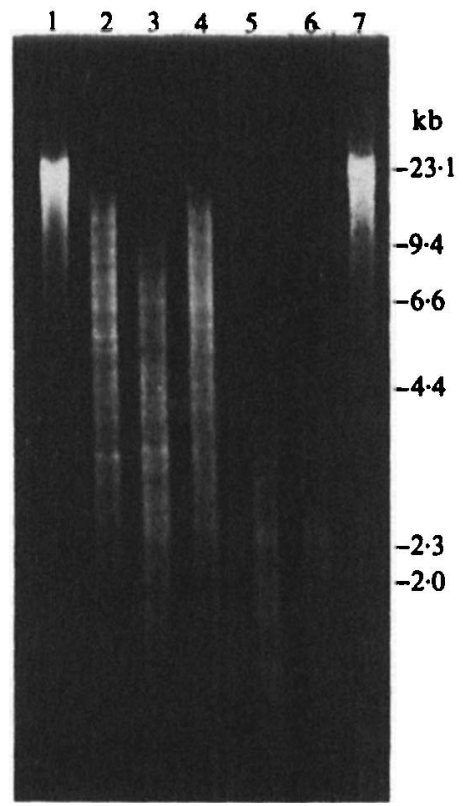

Fig. 2. Agarose gels of Anabaena 7120 vegetative (a) and heterocyst (b) DNAs treated with a variety of restriction enzymes. Track 1 is a control in which the DNA was incubated without enzyme. The identity of the other tracks is given in Table 1. The positions of molecular mass markers (generated by incubation of $\lambda$ DNA with HindIII) are shown to the right of each gel.

vegetative cell DNA was adhering to the purified heterocysts. This was tested by mixing two samples of Anabaena 7120. The first was a nitrogen-fixing culture from which heterocysts were to be isolated, and the second an ammonia-grown culture labelled in vivo with $\left[8-{ }^{3} \mathrm{H}\right]$ adenine. These were mixed at a ratio of $10: 1$, unlabelled to labelled culture, and heterocysts were then isolated as described in Methods. The amount of alkali-stable radioactivity (i.e. that in DNA) associated with the purified heterocysts was determined by liquid scintillation counting (data not shown). From these data, and assuming that heterocysts and vegetative cells have approximately the same DNA content (Simon, 1980; and see Dicussion) it was possible to calculate that, of the DNA in the final heterocyst pellet, not more than $13 \%$ was derived from vegetative cells. Thus, at least $87 \%$ of the DNA isolated from such a preparation was heterocyst DNA.

\section{Isolation of DNA from heterocysts}

The usual method employed to break heterocysts involved passage through a French pressure cell, but this caused considerable damage to the DNA and a gentler method had to be found. Addition of SDS to $2 \%$ final concentration, followed by heating at $70{ }^{\circ} \mathrm{C}$ for $10 \mathrm{~min}$, resulted in the removal of the cell contents of at least $90 \%$ of a sample of heterocysts, presumably via the pores at each end of the cell since the cell walls remained intact (Fig. 1b,d) This emptying of heterocysts could be seen by the change in appearance of the cells from bright to dark under phase-contrast optics (Fig. 1d) and the great increase in viscosity of the heterocyst sample as the DNA was released. DNA isolated in this way remained as a relatively tight band near the top of a $0.7 \%$ agarose gel and produced reproducible banding patterns when treated with many restriction endonucleases (Fig. 2). When French pressing was used during the isolation, the same enzymes produced a smear without clear banding (data not shown). 
Table 1. Effect of various restriction enzymes on cyanobacterial DNAs

\begin{abstract}
+ , Cleavage; - lack of cleavage. Recognition sequences are given in parentheses after each enzyme; the adenine or cytosine residues at which methylation will prevent cleavage are underlined. In the case of ClaI and $\mathrm{XbaI}$ this affects only a proportion of the sites recognized by the enzyme. Note that the isoschizomers HpaII and $M s p I$ respond differently to methylation: $H p a I I$ will cut the sequence ${ }^{\mathrm{Me}} \mathrm{CCGG}$, but not $\mathrm{C}^{\mathrm{Me}} \mathrm{CGG}$, while the reverse is true of $M s p I$. The numbers in parentheses indicate the tracks in Fig. 2 in which the Anabaena 7120 samples were electrophoresed.
\end{abstract}

\begin{tabular}{|c|c|c|c|c|}
\hline \multirow[b]{3}{*}{ Restriction enzyme } & \multicolumn{4}{|c|}{ Cleavage by restriction enzyme } \\
\hline & \multicolumn{2}{|c|}{$\begin{array}{l}\text { Source of } \\
\text { DNA ... Anabaena } 7120\end{array}$} & \multicolumn{2}{|c|}{ Anabaena CA } \\
\hline & Heterocyst & Vegetative & Heterocyst & Vegetative \\
\hline$X b a \mathrm{I}(\mathrm{T} \downarrow \underline{\mathrm{CTAGA}})$ & $+(2)$ & $+(2)$ & + & + \\
\hline HindIII $(\overline{\mathrm{A}} \downarrow \mathrm{AG}$ CTT $)$ & $+(3)$ & $+(3)$ & + & + \\
\hline$E c o R I$ (G」AATTC) & $+(4)$ & $+(4)$ & + & + \\
\hline HpaII (C\CGG) & $+(5)$ & $+(5)$ & + & + \\
\hline$M s p I(C \downarrow C G G)$ & $+(6)$ & $+(6)$ & + & + \\
\hline SalI $(\mathrm{G} \downarrow \mathrm{TCGAC})$ & $-(7)$ & $-(7)$ & - & - \\
\hline XhoI (C\TCGAG) & - & $-(8)$ & - & - \\
\hline$M b o \mathrm{I}(\downarrow \mathrm{GATC})$ & - & $-(9)$ & - & - \\
\hline ClaI (AT $\downarrow$ CGAT) & + & + & + & + \\
\hline
\end{tabular}

\title{
Restriction analysis
}

The purified DNAs were tested with a range of restriction enzymes (Table 1). Both heterocyst and vegetative cell DNAs from Anabaena 7120 and Anabaena CA were cut by the enzymes $X b a \mathrm{I}$, HindIII, EcoRI, ClaI, HpaII and MspI. However, as reported previously (Lambert \& Carr, 1984) the enzymes $X h o I$ and $S a l I$ failed to restrict Anabaena 7120 vegetative DNA. In addition, $M b o I$ did not restrict Anabaena 7120 vegetative DNA. Similarly, these three enzymes failed to restrict Anabaena 7120 heterocyst DNA and Anabaena CA vegetative cell and heterocyst DN.As. The restriction patterns obtained for Anabaena 7120 DNAs are shown in Fig. 2. To ensure that enzymes which failed to cut cyanobacterial DNA were still active, a control was done by incubating a mixture of $\lambda$ DNA and Anabaena 7120 vegetative DNA with the enzyme $X h o I$. The Anabaena 7120 DNA remained unrestricted, while the $\lambda$ DNA, having a single site for this enzyme, produced the expected two bands (data not shown), clearly indicating that, in the same reaction mixture, XhoI was active against $\lambda$ DNA, but not Anabaena 7120 DNA.

\section{DISCUSSION}

This paper describes the isolation of DNA from the heterocysts of two species of cyanobacteria. Because of losses during DNA extraction it is only possible to make approximate calculations of the cellular DNA content of heterocysts and vegetative cells, based on the yield of DNA from a known number of cells, but these have very similar values of approximately $18 \times 10^{-14} \mathrm{~g}$ per cell for Anabaena 7120. This confirms the findings of Simon (1980), who, using a chemical method for DNA estimation, obtained values for Anabaena variabilis (UTEX 1444) of 5.07 and $4.51 \times 10^{-14} \mathrm{~g}$ per cell for vegetative cells and heterocysts respectively and $22.4 \times 10^{-14} \mathrm{~g}$ per cell for vegetative cells of Anabaena cylindrica (UTEX 381). He also used a cytological method to assess the relative DNA content of heterocysts and vegetative cells in $A$. variabilis (UTEX 1444) and showed that the latter contained approximately $40 \%$ more DNA than the former.

The usual mechanical methods used initially to isolate and subsequently to disrupt heterocysts were inappropriate for the work outlined above, since they caused damage to the heterocyst DNA, precluding any meaningful restriction analysis and comparison with vegetative DNA. 
With care, however, it was possible to isolate heterocysts without recourse to mechanical disruption of vegetative cells and to release the DNA from the isolated heterocysts by heating at $70{ }^{\circ} \mathrm{C}$ for $10 \mathrm{~min}$ in the presence of $2 \%$ SDS. DNA isolated in this way was of sufficiently high quality to permit comparison of the restriction patterns with those of vegetative DNA. In agreement with previous workers, the enzymes $X h o I$ and $S a l I$ failed to cut the vegetative DNA of Anabaena 7120 (Lambert \& Carr, 1984). Nor did they cut the heterocyst DNA of Anabaena 7120 or the vegetative and heterocyst DNAs of Anabaena CA and Anabaena 7120, while all of these DNAs were cut by $X b a I$, HindIII, EcoRI, ClaI, HpaII and MspI. Lambert \& Carr (1984) concluded that the failure of some restriction enzymes to cleave the DNA of numerous cyanobacteria was due to methylation of the DNA and the data presented here supports their conclusions (see also Padhy et al., 1988). However, an additional explanation may be that some cyanobacterial DNAs are highly deficient in sites for certain restriction enzymes (Herrero et al., 1984). Indeed, Bancroft \& Wolk (1988) have shown that certain restriction enzymes (including Sall) cut Anabeana 7120 DNA very infrequently, generating very large fragments which can only be resolved by pulsed field gel electrophoresis.

The isolation of DNA from heterocysts has allowed an investigation into the possibility that changes in DNA methylation may be involved in the regulation of gene expression during heterocyst development. However, in the two species of cyanobacteria tested, the enzymes which cut or failed to cut vegetative DNA behaved similarly with heterocyst DNA. It seems likely, therefore, that heterocyst differentiation in cyanobacteria is not accompanied by extensive changes in methylation of the DNA, although a more detailed investigation with a wider range of cyanobacteria and restriction enzymes is needed to confirm this. Indeed, changes in methylation either of small, specific regions of the genome, or for short periods of the cell cycle, cannot be excluded by the techniques employed here, and must remain a possibility. Rearrangements or excision of sections of DNA are known to occur during development in several systems. Indeed Golden et al. (1985) have shown that during heterocyst development in Anabaena 7120, an $11 \mathrm{~kb}$ segment of heterocyst DNA between the nifK and nifD genes is excised, accompanied by a rearrangement of the genome near the nifV/S region. However, these two changes occurred at a late stage of heterocyst formation and their direct involvement in this developmental process must be questioned. Damerval et al. (1985) have confirmed the occurrence of these changes in the heterocysts of Nostoc 7906. In the work reported here, where the banding patterns of restriction digests were sufficiently clear to permit a comparison of heterocyst and vegetative DNAs, there were no readily apparent differences between the two. This reduces the likelihood of major rearrangements or excision of DNA during heterocyst differentiation, although it cannot eliminate more minor changes, which are unlikely to be detected using the techniques outlined here. There was, however, one possible minor difference between Anabaena 7120 vegetative and heterocyst DNAs. In Fig. $2(b)$ a band can be seen in both slots 1 and 7 just below the $6.6 \mathrm{~kb}$ marker. Its presence in the undigested sample (slot 1 ) suggests that it is a circular DNA molecule. However, as no circular DNA standards were used, it is not possible to judge its precise molecular mass. It may possibly correspond to the $11 \mathrm{~kb}$ fragment shown to be excised during heterocyst development in Anabaena 7120, which remains as a circular molecule following excision (Golden et al., 1985). However, although no such band is apparent in the vegetative DNA samples in Fig. 2(a), it can be seen faintly on the original negatives, indicating that it is present at a lower abundance than in heterocyst samples. There were no heterocysts in the cultures from which the vegetative DNA was prepared. Additionally, no such band could be seen on negatives of either vegetative or heterocyst DNAs from Anabaena CA. The significance of this band is thus unknown and the detection of any homology with the excised $11 \mathrm{~kb}$ fragment would require the use of that fragment as a hybridization probe.

\section{REFERENCES}

Adams, D. G. \& CARR, N. G. (1981). The developmental biology of heterocyst and akinete formation in cyanobacteria. CRC Critical Reviews in Microbiology 9, 45-100.
Allen, M. B. \& Arnon, D. I. (1955). Studies on nitrogen-fixing blue-green algae. I. Growth and nitrogen fixation by Anabaena cylindrica Lemm. Plant Physiology 30, 366-372. 
BANCROFT, I. \& WolK, C. P. (1988). Restrictionmapping the chromosomal DNA of Anabaena PCC 7120: pulsed field gel electrophoretic separation of fragments generated by restriction endonucleases that cleave that DNA infrequently. In Abstracts of the Sixth International Symposium on Photosynthetic Prokaryotes, Amsterdam, p. 14. Edited by L. R. Mur \& T. Burger-Wiersma.

Damerval, T., Franche, C., Rippka, R. \& CohenBAzIRE, G. (1985). $\mathrm{O}_{2}$-dependence of nif gene rearrangement in a het mutant of Nostoc. In Abstracts of the Fifth International Symposium on Photosynthetic Prokaryotes, Grindelwald, p. 123.

DOERFLER, W. (1983). DNA methylation and gene activity. Annual Review of Biochemistry 52, 93--124.

FAY, P. \& WALSBY, A. E. (1966). Metabolic activities of isolated heterocysts of the blue-green alga Anabaena cylindrica. Nature, London 209, 94-95.

FoGG, G. E. (1951). Growth and heterocyst production in Anabaena cylindrica Lemm. III. The cytology of heterocysts. Annals of Botany 15, 23-26.

Golden, J. W., Robinson, S. J. \& Haselkorn, R. (1985). Rearrangement of nitrogen fixation genes during heterocyst differentiation in the cyanobacterium Anabaena. Nature, London 314, 419-423.

Herrero, A., Elhai, J., Hohn, B. \& Wolk, C. P. (1984). Infrequent cleavage of cloned Anabaena variabilis DNA by restriction endonucleases from $A$. variabilis. Journal of Bacteriology 160, 781-784.

LAMBERT, G. R. \& CARR, N. G. (1984). Resistance of DNA from filamentous and unicellular cyanobacteria to restriction endonuclease cleavage. Biochimica et biophysica acta 781, 45-55.

LANG, N. J. \& FAY, P. (1971). The heterocysts of bluegreen algae. II. Details of ultrastructure. Proceedings of the Royal Society B178, 193-203.
Maniatis, T., Fritsch, E. F. \& Sambrook, J. (1982). Molecular Cloning: a Laboratory Manual. Cold Spring Harbor, NY: Cold Spring Harbor Laboratory.

Padhy, R. N., Hottat, F. G., Coene, M. M. \& Hoet, P. P. (1988). Restriction analysis and quantitative estimation of methylated bases of filamentous and unicellular cyanobacterial DNAs. Journal of Bacteriology 170, 1934-1939.

Simon, R. D. (1980). DNA content of heterocysts and spores of the filamentous cyanobacterium Anabaena variabilis. FEMS Microbiology Letters 8, 241-245.

Stanier, R. Y. \& Cohen-Bazire, G. (1977). Phototrophic prokaryotes: the cyanobacteria. Annual Review of Microbiology 31, 225-274.

UEDA, K. (1971). Die quantitative Bestimmung des DNS-Gehalts in den Zellen von Cyanophyceen durch Fluorochromierung mit Coriphosphin. Biochemie und Physiologie der Pfanzen 162, 439-449.

UEDA, K. \& SAWADA, M. (1972). DNA-content of akinete cells in Cylindrospermum. Cytologia 37, 519523.

VAN Den Hondel, C. A. M. J. J., van Leen, R. W., VAN ARKel, G. A., DUYVESTEYN, M. \& DE WAARD, A. (1983). Sequence-specific nucleases from the cyanobacterium Fremyella diplosiphon, and a peculiar resistance of its chromosomal DNA towards cleavage by other restriction enzymes. FEMS Microbiology Letters 16, 7-12.

WolK, C. P. (1982). Heterocysts. In The Biology of Cyanobacteria, pp. 359-386. Edited by N. G. Carr \& B. A. Whitton. Oxford: Blackwell Scientific Publications. 